\title{
Análises Microbiológicas de Água Tratada e Não Tratada Na Região de Botucatu - São Paulo
}

\author{
Silvia Janine Veiga (I), Priscilla Camilla Zucco dos Santos (I), \\ Rafaela Cardoso Gomes (I), Victor Alessandro Abib Pastore (I), \\ Otávio Augusto Martins (I), Germano Francisco Biondi (I) \\ (I) UNESP - Universidade Estadual Paulista "Júlio de Mesquita Filho" (Distrito de Rubião Junior \\ $\mathrm{s} / \mathrm{n}^{\circ}, 18.618-970$ Botucatu, São Paulo, Brasil)
}

\section{Resumo}

A água potável é indispensável para a vida de todo ser vivo, encontrada em pequenas quantidades em nosso planeta e limitada. Para poder ser consumida a água deve ser incolor, inodora, insípida e livre de microorganismos patogênicos. A presença destes micro-organismos na água pode ocorrer devido a contaminação por grande quantidade de fezes humanas e, quando encontrados na água, significa que a mesma recebeu esgotos domésticos. O presente trabalho teve por objetivo avaliar a condição higiênico-sanitária da água tratada e não tratada (água de poço) da região de Botucatu, São Paulo. A pesquisa foi realizada com 53 amostras de água, sendo 47 de água tratada e 6 de água de poço, realizadas no Laboratório de Microbiologia do Serviço de Orientação à Alimentação Pública (SOAP), Departamento de Higiene Veterinária e Saúde Pública, Faculdade de Medicina Veterinária e Zootecnia (FMVZ - UNESP - Campus de Botucatu/SP) no período de janeiro a junho de 2014. Foram realizadas as seguintes análises microbiológicas: contagem de bactérias mesófilas aeróbias viáveis utilizando a metodologia Petrifilm® com diluições $10^{-1} \mathrm{e}$ $10^{-2}$, número mais provável (NMP) de coliformes termotolerantes e coliformes totais pela metodologia de tubos seriados em caldo lauril, sendo a primeira fileira de lauril dupla concentração. Apenas 4,26\% de água tratada apresentaram resultado $>1,5 \times 10^{2} \mathrm{UFC} / \mathrm{mL}$ estimado para contagem de bactérias mesófilas aeróbias viáveis. Todas as amostras

\footnotetext{
Referência:

Silvia Janine Veiga, Priscilla Camilla Zucco dos Santos, Rafaela Cardoso Gomes, Victor Alessandro Abib Pastore, Otávio Augusto Martins, Germano Francisco Biondi. Análises Microbiológicas de Água Tratada e Não Tratada Na Região de Botucatu - São Paulo. In: Anais do 12 Congresso Latinoamericano de Microbiologia e Higiene de Alimentos - MICROAL 2014 [= Blucher Food Science Proceedings, num.1, vol.1]. São Paulo: Editora Blucher, 2014.

DOI 10.5151/foodsci-microal-160
} 
apresentaram resultado ausente/100 $\mathrm{mL}$ para NMP de coliformes termotolerantes e coliformes totais. Todas as amostras de água de poço apresentaram valores altos para contagem de bactérias mesófilas aeróbias viáveis (> 2,5 x 103 $\mathrm{UFC} / \mathrm{mL}$ ), 83,33\% apresentaram NMP de coliformes totais $>100 / 100 \mathrm{~mL}$ e $16,67 \%$ apresentaram $9,2 / 100 \mathrm{~mL}$ para coliformes termotolerantes, resultados acima do permitido pela legislação vigente onde estabelece Ausência/100 mL. Apesar da Portaria n 518 do Ministério da Saúde não estabelecer um padrão microbiológico para contagem de bactérias mesófilas aeróbias viáveis em água para consumo humano, as amostras de água de poço foram consideradas não aptas para consumo devido o alto grau de contaminação. Sugere-se neste caso a adoção de práticas que minimizem a contaminação da água.

Palavras-Chave: Água Tratada, Água Não Tratada, Qualidade, Microbiologia

\section{Agência de Fomento:}

